\title{
Paleomagnetic results of Tertiary sediments from Corsica: evidence of post-Eocene rotation
}

\author{
L. Vigliotti \\ Istituto di Geologia Marina, CNR. Via Zamboni 65, 40127 Bologna, (Italy) \\ D.V. Kent \\ Lamont-Doherty Geological Observatory, Palisades, NY 10964 (U.S.A.)
}

(Received and accepted May 22, 1989)

\begin{abstract}
Vigliotti, L. and Kent, D.V., 1990. Paleomagnetic results of Tertiary sediments from Corsica: evidence of post-Eocene rotation. Phys. Earth Planet. Inter., 62: 97-108.

Middle Eocene (Lutetian) and Lower to Middle Miocene (Burdigalian-Langhian) sediments from Corsica have been investigated in a paleomagnetic study to constrain the amount and timing of tectonic rotation of the Corsican block with respect to Sardinia and stable Eurasia. The sediments are generally characterized by weak and unstable magnetization, and only five Eocene and five Miocene sites out of 23 sites sampled provided interpretable data.

Our best estimate for the Eocene paleomagnetic field for Corsica suggests $\sim 37^{\circ}$ of counter-clockwise rotation, and no latitudinal change, with respect to stable Eurasia in post-Eocene time. This is similar to the amount of tectonic rotation documented from Oligo-Miocene volcanics from Sardinia, which is therefore consistent with Corsica and Sardinia being part of the same tectonic block since at least the early to middle Tertiary. Paleomagnetic results from the Miocene sites may represent remagnetizations but the presence of reversed polarity magnetization at three of the five accepted sites indicates acquisition before the late Pleistocene. The final rotation history of Corsica nevertheless is left unresolved.
\end{abstract}

\section{Introduction}

The Corsica-Sardinia microplate is an important element in models for the tectonic evolution of the western Mediterranean. Paleomagnetism has played a key role in unravelling the tectonic movements and paleogeography of Sardinia. Although, geologically, the two islands are considered a single block, paleomagnetic data from Corsica give hardly any information which would help us to evaluate the possibility of relative movements between Sardinia and Corsica.

The few and controversial paleomagnetic data from Corsica are confined to the late Paleozoic volcanics of the northwestern part of the island
(Nairn and Westphal, 1968; Westphal, 1976; Westphal et al., 1976). The results are not very clear and they seem to show $\sim 30^{\circ}$ counterclockwise (ccw) rotation of the island with respect to stable Europe in post-Paleozoic times. In contrast, Sardinia has been intensively studied from a paleomagnetic point of view. Data for the late Paleozoic (Zijderveld et al., 1970; Westphal et al., 1976; Storetvedt and Markhus, 1978; Edel et al., 1981) show a rotation of $\sim 70^{\circ}$ of the island with respect to stable Europe and a somewhat larger rotation $\left(-90^{\circ}\right)$ according to the data published by Horner and Lowrie (1981) on Triassic and Jurassic limestones. The Cretaceous history of rotation of Sardinia is not documented by 


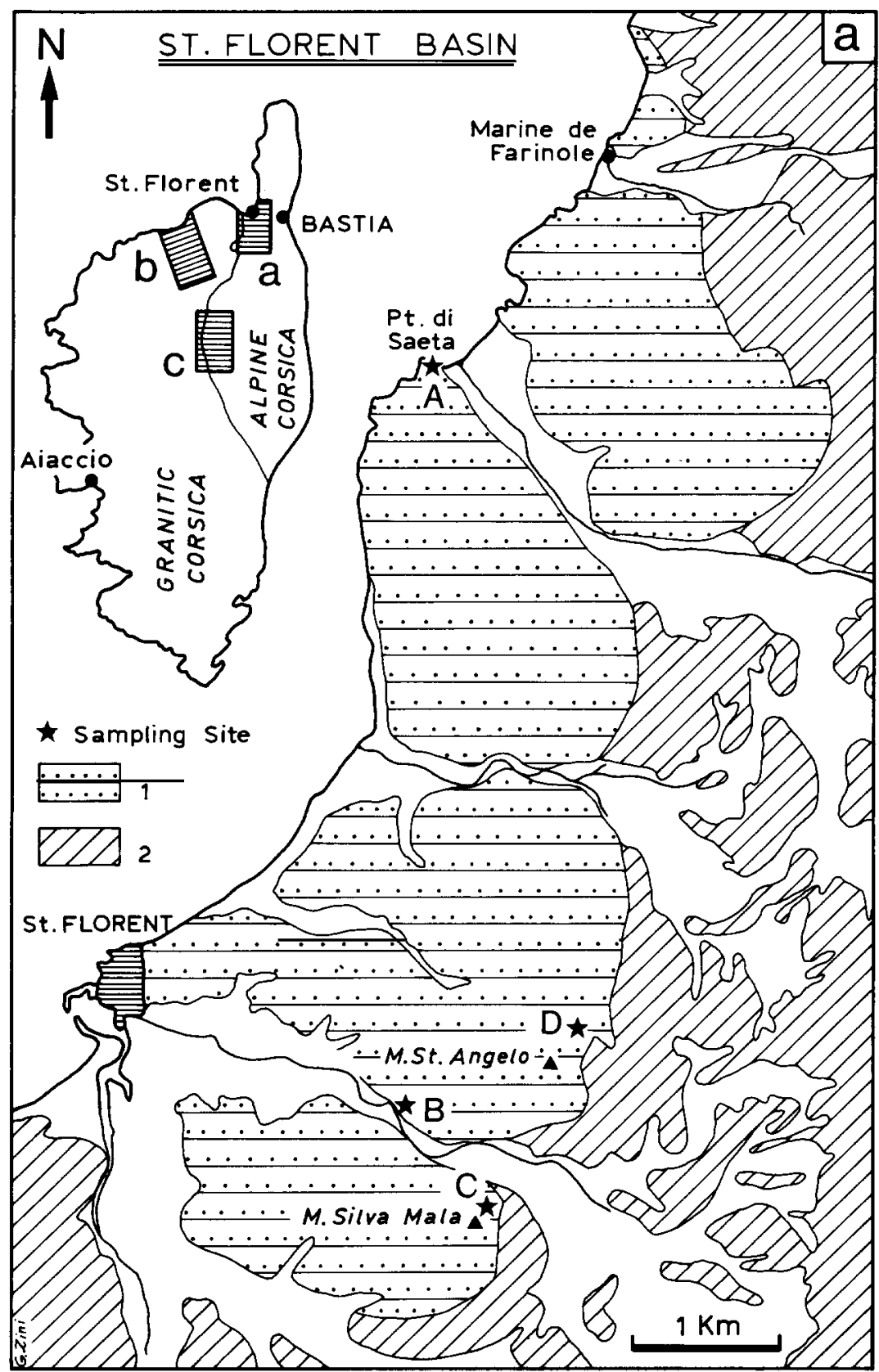

Fig. 1. Geological sketch-map of the three Tertiary sedimentary basins sampled for paleomagnetic study. (a) St. Florent basin (redrawn after Dallan and Puccinelli, 1986). 1= Miocene deposits (Neoautochthonous of St. Florent); $2=$ Alpine units. (b) Balagne basin (redrawn after Nardi et al., 1971). 1= Crystalline basement (Paleozoic); 2 = Tertiary autochthonous complex; $3=$ Mesozoic units. (c) Francardo basin. 1 = Miocene deposits; 2 = Alpine units; 3 = Crystalline basements (Paleozoic). (For technical reasons, Fig. 1(b) and (c) appear on pp. 99 and 100.) 


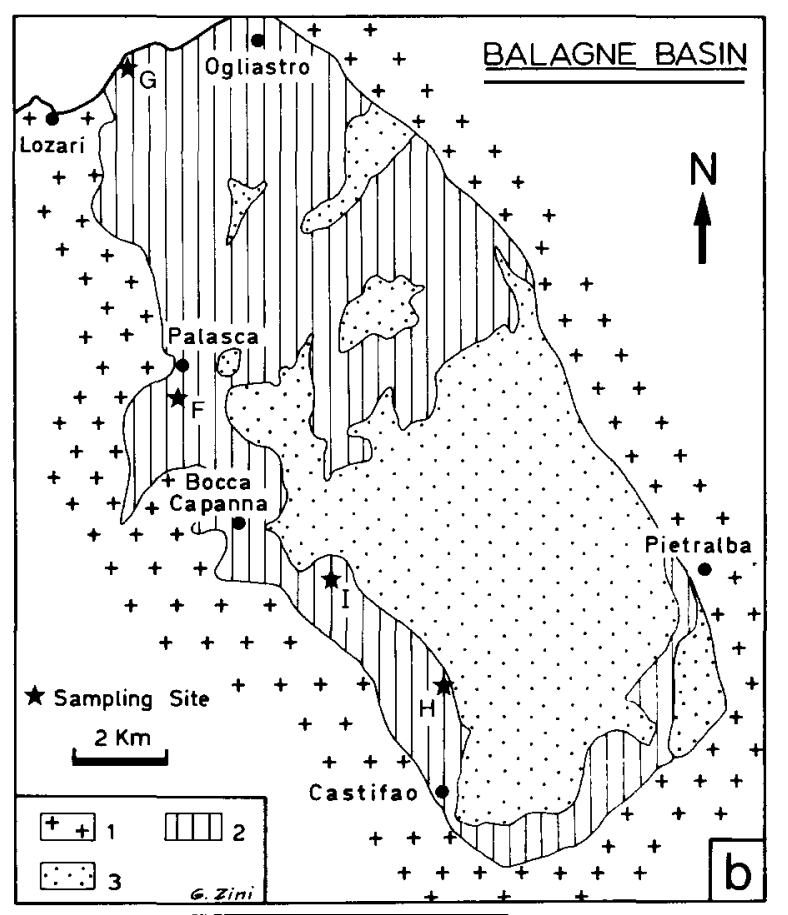

Fig. 1 (continued).

paleomagnetic data, but the extensive Tertiary volcanics have been the subject of numerous investigations (De Jong et al., 1969, 1973; Bobier, 1974; Manzoni, 1974; Bellon et al., 1977; Edel and Lortscher, 1977; Edel, 1979; Montigny et al., 1981). It is well established that Sardinia underwent a counter-clockwise rotation of $\sim 35^{\circ}$ but the detailed timing of the relative motion(s) is somewhat uncertain. Bellon et al. (1977) suggested a translation of the island between 29 and $17 \mathrm{Ma}$, followed by a relatively rapid $\mathrm{ccw}$ rotation ending at the latest at $15 \mathrm{Ma}$. In a recent study and compilation, Montigny et al. (1981) advocated an older age for the rotation, between 20.5 and 19 $\mathrm{Ma}$, and suggested a $1000 \mathrm{~km}$ northward drift of the island during the last $19 \mathrm{Ma}$.

There is no Tertiary volcanism in Corsica and this fact largely accounts for the present absence of Tertiary paleomagnetic data for the island. The aim of this work is to investigate the paleomagnetism of Tertiary sediments from Corsica, to compare the amount and timing of the rotation of Corsica relative to Sardinia and Eurasia.

\section{Geological setting and sampling}

The main paleomagnetic results were obtained from Eocene and Miocene sediments in three sedimentary basins in northern Corsica: St. Florent (Fig. 1a), Balagne (Fig. 1b) and Francardo (Fig. 1c). According to Delcey et al. (1964), these basins share a similar paleogeographic history. The clastic sequences originate from the disruption of the same Hercynian Massif crystalline basement which was covered by transgressive nummulitic deposits composed generally of conglomerates, but locally of limestones and calcarenites.

The Balagne was most removed from the Alpine front. This region was above sea level from the late Paleozoic until a major transgression in the middle-upper Lutetian, which marks the establishment of a tectonic depression that preceded the emplacement of the allochthonous units in Alpine Corsica (Nardi et al., 1978). Transgressive autochthonous formations show a simple structure with sub-horizontal trends in the basin, contrasting with the complex structure of the allochthonous terrains. Along the eastern margins of the Balagne the western overthrust front of the Alpine nappes involved the Lutetian sedimentary rocks and it is not easy to find outcrops that were not clearly involved in these tectonic movements.

In this study, attention was focused on the nummulitic limestones, which are typically represented by coarsely bedded gray limestones and calcarenites. Frequently they are rich in benthic foraminifera and especially nummulites of middle to late Lutetian age (Denizot, 1952; Delcey et al., 1964). The calcarenites crop out generally as lenses; to the north of Castifao (Fig. 1b), they are as thick as $200-300 \mathrm{~m}$. These rocks were sampled in the Balagne (Fig. $1 \mathrm{~b}$; sites $F, \mathrm{H}, \mathrm{I}$ ) and in the region of Francardo (Fig. 1c; site $L$ and a rejected site). In the region of Lozari (Fig. 1b, site G), we sampled the upper Lutetian Lozari Sandstones (Nardi et al., 1978) which consist of gray, wellbedded feldspathic sandstones, with intercalations of silts and claystone. This formation outcrops in seacliffs and can be considered as a different facies of the nummulitic limestones. Eocene sediments were also sampled in the southeast region around Solenzara. Here the outcrops are further 


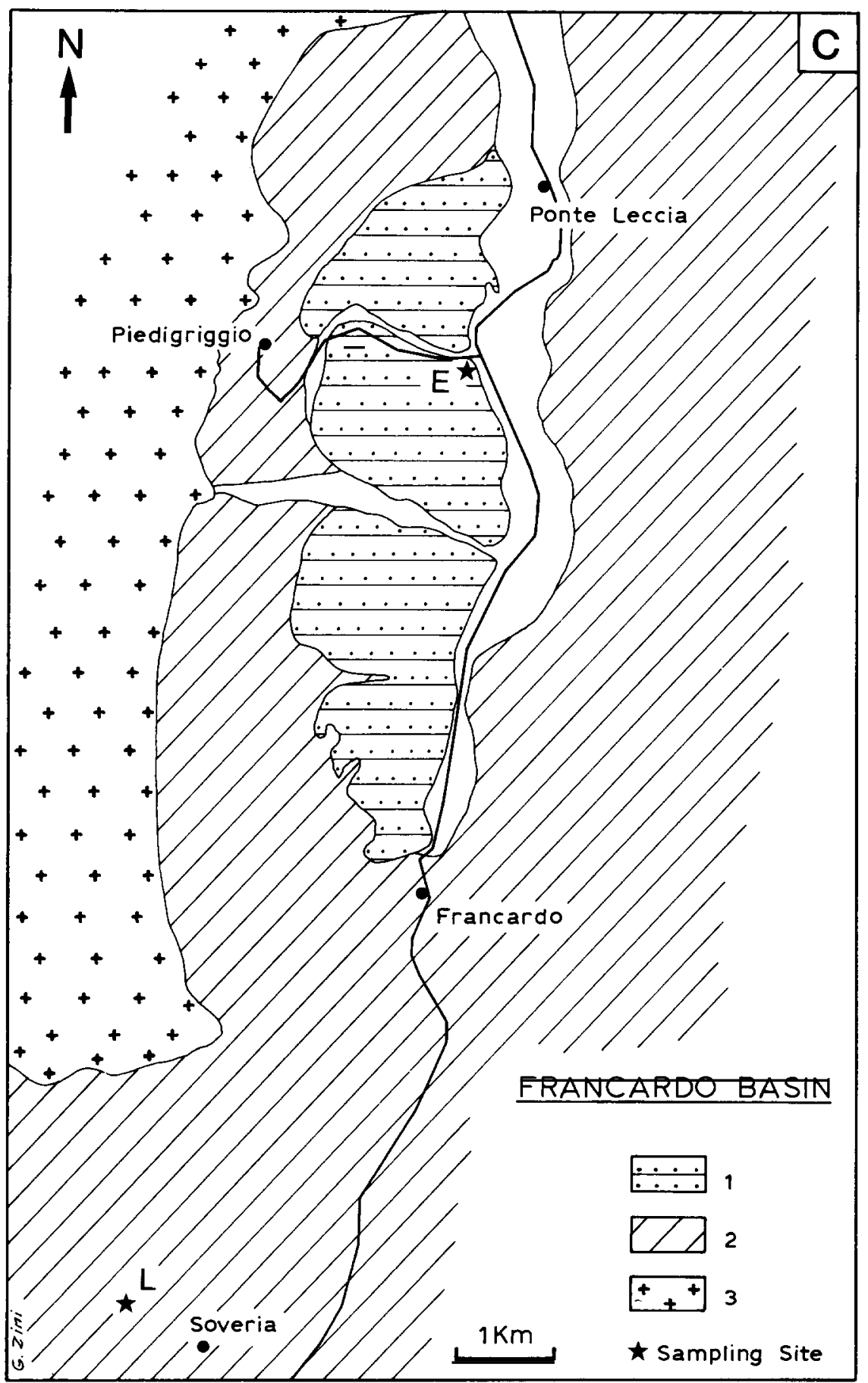

Fig. 1 (continued). 
from the effect of Alpine tectonics, but the rocks showed very weak magnetization unstable to both alternating field (AF) and thermal demagnetization, so the five sites collected in this region are not considered further.

Post-tectonic Miocene (Burdigalian-Tortonian) deposits with transgressive and coastal molasse facies exist around St. Florent (Fig. 1a), in the vicinity of Aleria, in the region of Francardo (Fig. 1c), and at Bonifacio. Miocene rocks were sampled in all these four areas (12 sites) including classical units such as the tuffs of Capo Bianco in the Bonifacio region, and the Minette de Sisco along the northwestern coast. In spite of the wide geographical distribution of sampling, very few areas proved to be suitable for paleomagnetic studies.

The neo-autochthonous Miocene sequence of St. Florent (sites A, B, C and D plus three rejected sites; Fig. 1a) is characterized by a BurdigalianLower Langhian marine sequence of 100-400-m thickness, which largely consists of fossiliferous sandy limestones deposited in a nearshore environment. These molasse-like sediments unconformably transgressed all Alpine nappe structures; a later phase of folding is responsible for the synclinal structure of the Miocene of St. Florent (Dallan and Puccinelli, 1986). A conglomeratic formation of continental facies overlies these marine deposits near the village of St. Florent and probably indicates the emergence of the region in post-Langhian times.

Between the granitic framework of Corsica and the Alpine Nappes exists the inner basin of Francardo (Fig. 1b) which has been active since the Jurassic. Here the Miocene deposits are more coarse grained, so it was possible to sample only one site (E).

\section{Results}

For this study 191 hand-samples were collected from 23 sites. Two to four specimens were drilled from each hand-sample. The measurements were carried out with an SCT cryogenic magnetometer at the paleomagnetic laboratory at the LamontDoherty Geological Observatory. Some samples with a stronger magnetization were measured with a Digico spinner magnetometer. Components of magnetization were identified on orthogonal demagnetization diagrams, and directions were

TABLE 1

List of paleomagnetic data and statistical parameters from rocks of Eocene age, before and after tectonic correction, after cleaning

\begin{tabular}{|c|c|c|c|c|c|c|}
\hline Site & $a / b$ & $D(\mathrm{deg})$ & $I(\mathrm{deg})$ & $R$ & $K$ & $\alpha_{95}$ \\
\hline \multirow[t]{2}{*}{$\mathrm{F}$} & $17 / 21$ & 119.8 & -39.0 & 16.795 & 78 & 4.1 \\
\hline & & 151.0 & -47.2 & 16.801 & 80 & 4.0 \\
\hline \multirow[t]{2}{*}{ G } & $13 / 26$ & 169.4 & -55.2 & 12.453 & 22 & 9.1 \\
\hline & & 190.7 & -46.5 & 12.453 & 37 & 6.9 \\
\hline \multirow[t]{2}{*}{$\mathbf{H}$} & $12 / 15$ & 148.6 & -47.3 & 11.746 & 43 & 6.7 \\
\hline & & 184.7 & -63.6 & 11.830 & 65 & 5.4 \\
\hline \multirow[t]{2}{*}{ I } & $10 / 14$ & 206.6 & -66.4 & 9.689 & 28 & 9.1 \\
\hline & & 249.6 & -40.7 & 9.689 & 29 & 9.1 \\
\hline \multirow[t]{2}{*}{$\mathbf{L}$} & $10 / 21$ & 325.5 & +53.5 & 9.515 & 19 & 11.5 \\
\hline & & 313.2 & +50.6 & 9.520 & 19 & 11.5 \\
\hline \multirow[t]{2}{*}{ (La) } & 4 & 354.1 & +44.8 & 3.990 & 288 & 5.4 \\
\hline & & 344.2 & +46.9 & 3.989 & 270 & 5.6 \\
\hline \multirow[t]{2}{*}{ (Lb) } & 6 & 302.3 & +54.5 & 5.950 & 100 & 6.7 \\
\hline & & 292.5 & +48.3 & 5.949 & 98 & 6.8 \\
\hline \multirow{2}{*}{\multicolumn{2}{|c|}{$\mathrm{G}+\mathrm{H}+\mathrm{L}($ mean $)$}} & 153.0 & -52.5 & 2.976 & 84 & 13.5 \\
\hline & & 166.0 & -57.7 & 2.831 & 12 & 37.5 \\
\hline
\end{tabular}

$a$ : Number of specimens used in the calculation of the mean data. $b$ : Number of measured specimens. Geomagnetic pole position from site $\mathrm{F}\left(42.6^{\circ} \mathrm{N}, 9.0^{\circ} \mathrm{E}\right)$. Pole latitude $=62.6^{\circ} \mathrm{N}$; pole longitude $=257.1^{\circ} \mathrm{E}$. 
TABLE 2

List of paleomagnetic data and statistical parameters from rocks of Miocene age, before and after tectonic correction, after cleaning

\begin{tabular}{|c|c|c|c|c|c|c|}
\hline Site & $a / b$ & $D(\mathrm{deg})$ & $D$ (deg) & $R$ & $\boldsymbol{K}$ & $\alpha_{95}$ \\
\hline \multirow[t]{2}{*}{ A } & $20 / 30$ & 359.0 & +63.4 & 19.721 & 68 & 4.0 \\
\hline & & 336.1 & +50.0 & 19.738 & 72 & 3.1 \\
\hline \multirow[t]{2}{*}{ B } & $18 / 18$ & 202.8 & -62.6 & 17.848 & 112 & 3.3 \\
\hline & & 173.7 & -53.2 & 17.848 & 112 & 3.3 \\
\hline \multirow[t]{2}{*}{$\mathrm{C}$} & $16 / 22$ & 193.2 & -58.2 & 15.705 & 50 & 5.2 \\
\hline & & 166.2 & -42.0 & 15.720 & 54 & 5.1 \\
\hline \multirow[t]{2}{*}{ D } & $10 / 11$ & 182.5 & -65.8 & 9.821 & 50 & 6.9 \\
\hline & & 155.8 & -41.7 & 9.821 & 50 & 6.9 \\
\hline \multirow[t]{2}{*}{ E } & $19 / 23$ & 353.0 & +64.3 & 18.854 & 123 & 3.0 \\
\hline & & 288.3 & +49.7 & 18.855 & 124 & 3.0 \\
\hline \multicolumn{2}{|c|}{ Overall mean } & 186.6 & -63.3 & 4.977 & 177 & 5.8 \\
\hline \multicolumn{2}{|c|}{$(\mathrm{A}-\mathrm{E})$} & 153.0 & -49.5 & 4.820 & 22 & 16.6 \\
\hline \multirow{2}{*}{\multicolumn{2}{|c|}{$\mathrm{B}+\mathrm{C}+\mathrm{D}$ (mean) }} & 193.2 & -62.4 & 2.989 & 186 & 9.1 \\
\hline & & 164.6 & -45.9 & 2.975 & 81 & 13.8 \\
\hline
\end{tabular}

$a$ : Number of specimens used in the calculation of the mean data. $b$ : Number of measured specimens.

calculated as far as practicable according to principal component analysis (Kirshvink, 1980). Paleomagnetic data are summarized in Tables 1 and 2 and are discussed below according to age.

Most of the sampled sites proved to be too weakly magnetized and/or too unstable against AF or thermal demagnetization to be paleomagnetically useful. After two field sessions only 10 sites (five of Eocene age, and five of Miocene age; as designated by letters above) yielded characteristic magnetizations that provide some information on Tertiary paleomagnetic directions of Corsica.

\subsection{Results from sites of Eocene age}

The natural remanent magnetization (NRM) of the nummulitic limestones is weak, generally $10^{-5}$ A $\mathrm{m}^{-1}$, except at site $\mathrm{L}$, where it is about one order of magnitude stronger. Thermal demagnetization gave more consistent results than $\mathrm{AF}$, although for some samples successive application of these demagnetization techniques has been used. The paleomagnetic record of the rock appears to be complex and the behaviour is not uniform among the sites. Indeed, only five of the 11 sites sampled showed a characteristic magnetization. The sediments typically had two components of magnetization: one aligned along the present field, which is removed after AF treatment of about $20-40 \mathrm{mT}$ or thermal treatment of $200^{\circ} \mathrm{C}$, and another of higher coercivity and/or unblocking temperature with reversed polarity for all the sites except $\mathbf{L}$. This characteristic remanence, however, is completely destroyed typically between 340 and $400^{\circ} \mathrm{C}$, which made it difficult to obtain a good trajectory on the demagnetization diagrams; stable end-point and minimum dispersion criteria were therefore used to obtain representative site mean directions. All the results are reported in Table 1 and plotted on stereonet, site by site, in Fig. 2.

Site $\mathrm{F}$ is the only Eocene site whose geologic setting is clearly autochthonous. The 17 characteristic sample directions of the site are well grouped about a mean of declination/inclination of $119.8^{\circ} /-39.0^{\circ}\left(\alpha_{95}=4.1^{\circ}\right)$. After correction for the monoclinal bedding dips, the mean direction becomes $151.0^{\circ} /-47.2^{\circ}$ (Fig. $2 \mathrm{a}$ ).

A direction very close to that of site $F$ was exhibited by the 12 specimens from site $\mathrm{H}$ (Fig. $2 \mathrm{~b})$, but only before tectonic correction $\left(148.6^{\circ}\right.$, $\left.-47.3^{\circ}, \alpha_{95}=6.7^{\circ}\right)$. After tilt correction, the direction $\left(184.7^{\circ} /-63.6^{\circ}, \alpha_{95}=5.4^{\circ}\right)$ is significantly different from that of site $F$.

Site G consists of the so-called Lozari Sandstones (Nardi et al., 1978). The magnetic record of the ancient field is poor and only a few samples 
exhibited a characteristic magnetization. Many samples are weakly magnetized or unstable. For other samples, the directions obtained during demagnetization, before they became too weak for further investigation, did not change appreciably from the NRM direction. The 13 specimen directions shown in Fig. $2 \mathrm{c}$ gave a mean of $169.4^{\circ} /-$ $55.2^{\circ}\left(\alpha_{95}=9.1^{\circ}\right)$; after tectonic correction the direction becomes $190.7^{\circ} /-46.5^{\circ}\left(\alpha_{95}=6.9^{\circ}\right)$.

Site $\mathrm{L}$, near the village of Soveria, in the Francardo region, does not show bedding because of heavy jointing. The remanence is not very stable and a characteristic remanence could be isolated in only less than half (10) of the specimens, which
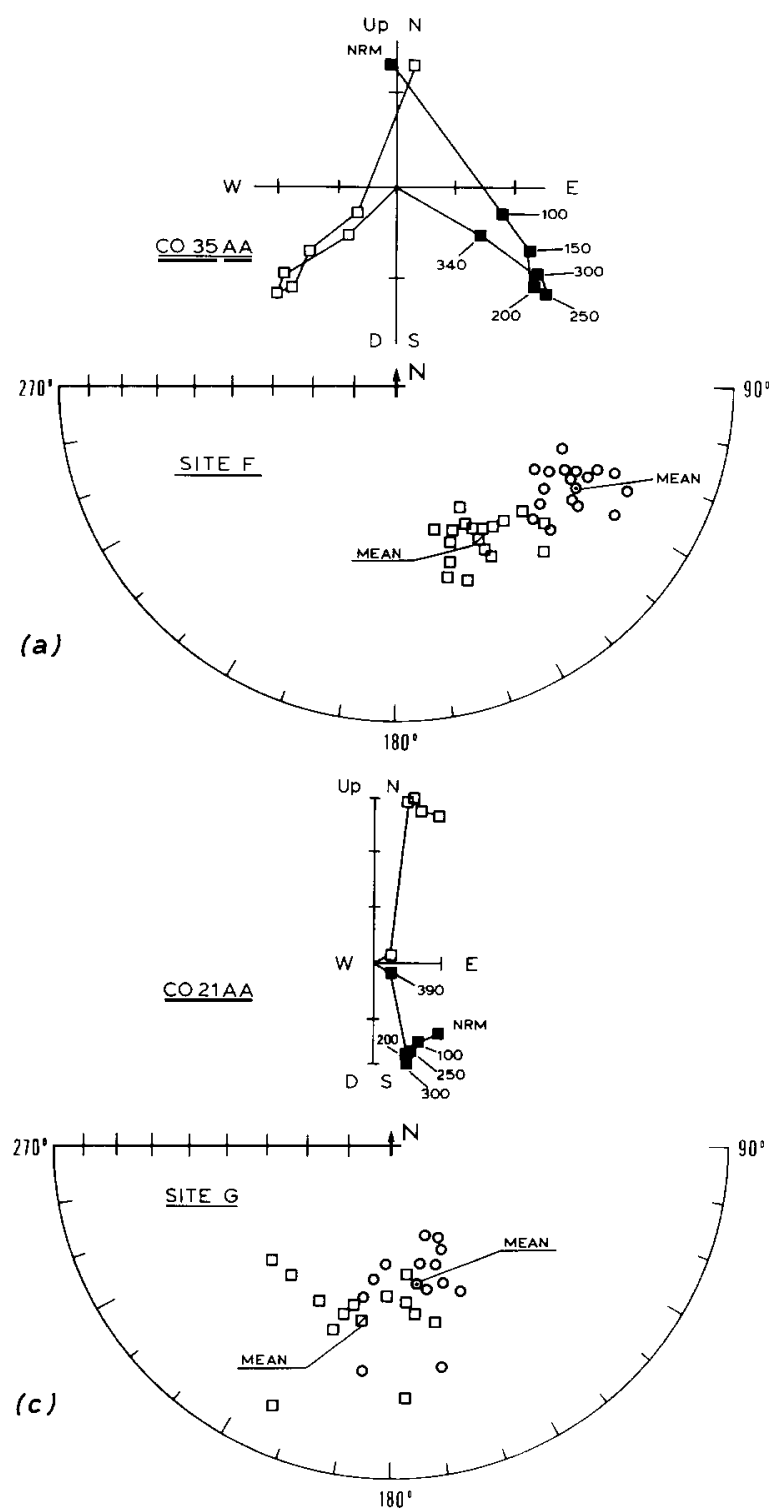
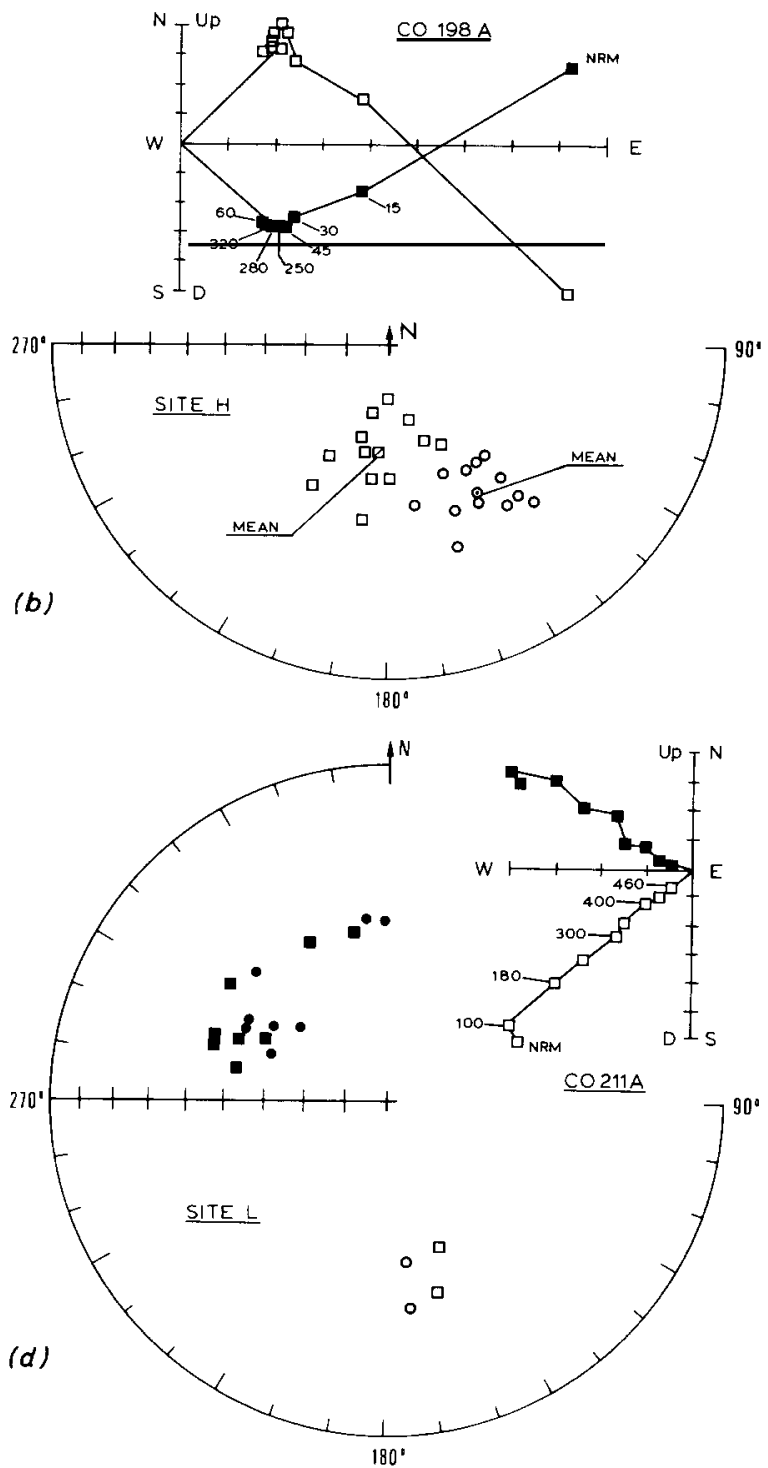

Fig. 2. Stereographic projection of paleomagnetic mean directions before (circle) and after (square) tilt correction for sites of Eocene age. Open symbols for negative inclinations. Orthogonal demagnetization plot in geographic co-ordinates. Solid squares, projection on the horizontal axes; open circles, projection on vertical plane. Thermal steps are marked in degrees Celsius ( ${ }^{\circ} \mathrm{C}$ ). 


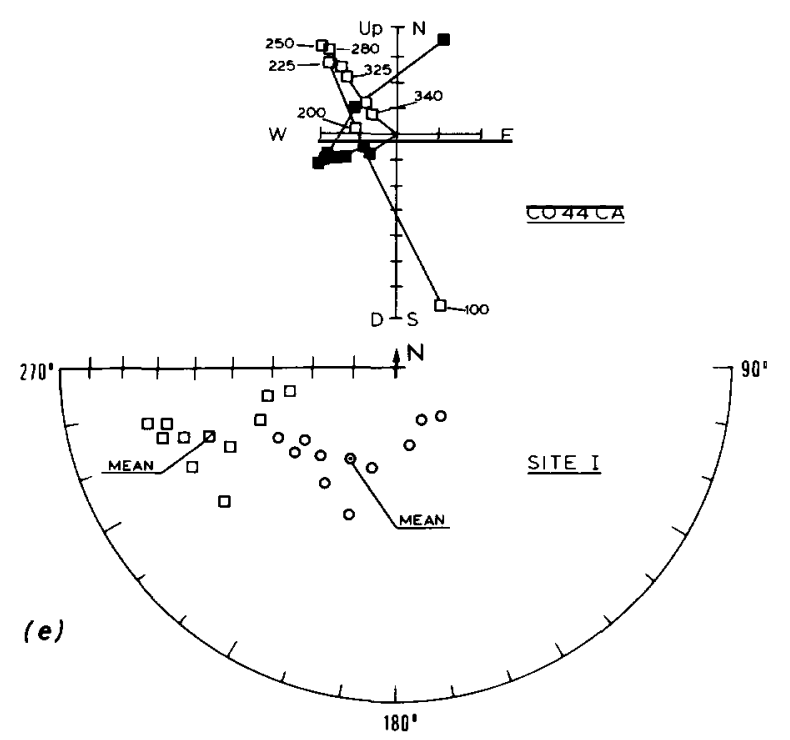

Fig. 2 (continued).

give a mean direction of $325.5^{\circ} / 53.5^{\circ}, \alpha_{95}=$ $11.5^{\circ}\left(313.2^{\circ} / 50.6^{\circ}\right.$ after tilt correction) (Fig. 2d). There is, however, the suggestion that the results represent two populations, one (La) with directions aligned more north-south in four samples with normal and reversed polarity $\left(354.1^{\circ} / 44.8^{\circ}, \alpha_{95}=5.6^{\circ} ; 344.2^{\circ} / 46.9^{\circ}\right.$ after tilt correction), and the other (Lb) with more eastwest directions in six samples of only normal polarity $\left(302.3^{\circ} / 54.5^{\circ}, \alpha_{95}=6.7^{\circ} ; 292.5^{\circ} / 48.3^{\circ}\right.$ after tilt correction).

Site I was clearly affected by Alpine tectonics, as testified by a slight foliation of the rock. This may account for the mean direction obtained for the 10 specimens out of 14 studied, which is anomalous with respect to the other Eocene sites either before $\left(206.6^{\circ} /-66.4^{\circ}, \alpha_{95}=9.1^{\circ}\right)$ or after $\left(249.6^{\circ} /-40.7^{\circ}\right)$ tectonic correction (Fig. 2e).

\subsection{Results from sites of Miocene age}

The NRM intensities of the Miocene sediments range from about $10^{-4}$ to $5 \times 10^{-5} \mathrm{~A} \mathrm{~m}^{-1}$. Representative specimens from each site were $A F$ and thermally demagnetized; either technique was generally effective in isolating the stable component of magnetization and AF demagnetization was used most. In contrast to the Eocene sediments, the remanence of the Miocene samples was relatively uncomplicated. After the removal of a small overprint in 10-30 mT AF, consistent results were obtained from the five accepted sites: sites B (Fig. 3a) and $C$ (Fig. 3b) exhibited reversed magnetization, sites A (Fig. 3c) and E (Fig. 3d) had normak ones, and in site $\mathrm{D}$ both polarities were present (Fig. 3e). Before tectonic corrections, the paleomagnetic directions tended to lie along a north-south axis similar to that of the present-day field. The tectonic tilt correction is similar for all samples within each site, but varies sufficiently between sites for an overall fold or tilt test. Cleaned directions before and after tilt correction are reported in Table 2 and call for the following remarks.

Site B showed a stable magnetization with well-defined reversed direction with little or no overprint. The mean direction calculated in geographic coordinates for 18 specimens is $202.8^{\circ} /$ $62.6^{\circ}, \alpha_{95}=3.3^{\circ}$ (Fig. 3a).

Two samples from site $\mathrm{C}$ (six specimens) were apparently affected by lightning (strong NRM rapidly decreased by AF treatment); neither thermal nor AF cleaning was able to remove this overprint completely, so these samples were rejected. One more specimen showed unresolved magnetizations and it was not taken into account in the calculation of the overall mean from 16 specimens in geographic co-ordinates of $193.2^{\circ} /-58.2^{\circ}, \alpha_{95}=5.2^{\circ}$ (Fig. 3b).

Normal and reversed magnetizations, apparent even before demagnetization, were found in site D. One sample changed its polarity from normal to reversed after magnetic cleaning, but one specimen from the same sample showed an anomalous direction and was rejected. The overall mean for 10 specimens from this site in geographic coordinates is $182.5^{\circ} /-65.8^{\circ}, \alpha_{95}=6.9^{\circ}$ (Fig. 3c).

Site A was the only one in the region of St. Florent to show uniformly normal polarity. The stability of remanence is poor, with median destructive fields hardly exceeding $10 \mathrm{mT}$, and the Zijderveld plots do not always appear to be clearly linear. For this reason, 10 specimens were rejected. The mean direction in geographic co-ordinates of the remaining 20 specimens from the site is $359^{\circ} / 63.4^{\circ}, \alpha_{95}=4.0^{\circ}$ (Fig. 3d). 
Paleomagnetic directions from site E (Francardo Basin) also show uniformly normal polarities and gave a very similar mean direction of $353.0^{\circ} / 64.3^{\circ}, \alpha_{95}=3.0^{\circ}$ for 19 specimens in geographic co-ordinates (Fig. 3e).

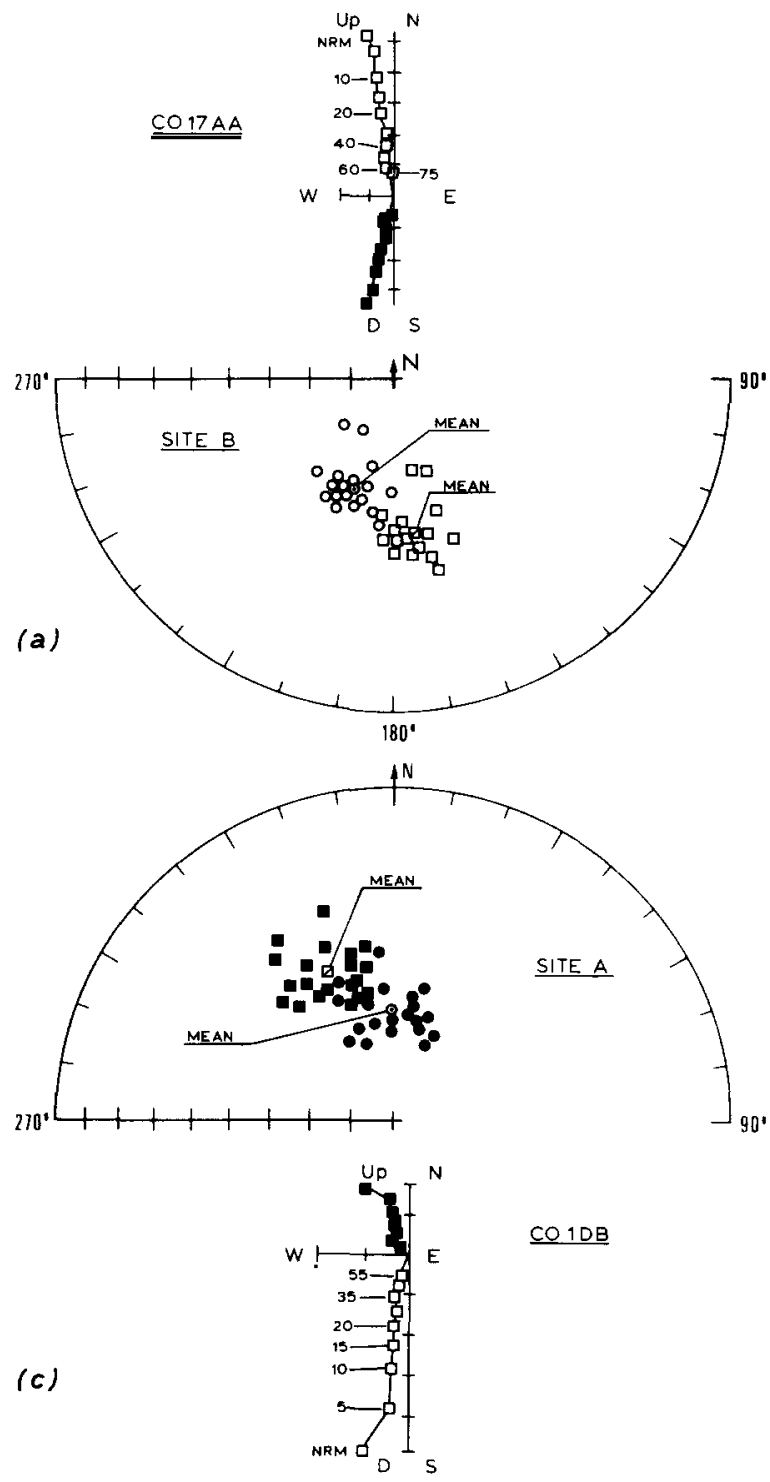

\section{Interpretation}

According to Westphal et al. (1986), the apparent polar wander path for stable Eurasia gives an Eocene pole at $76^{\circ} \mathrm{N}, 161^{\circ} \mathrm{E}\left(\alpha_{95}=3^{\circ}\right)$ and a
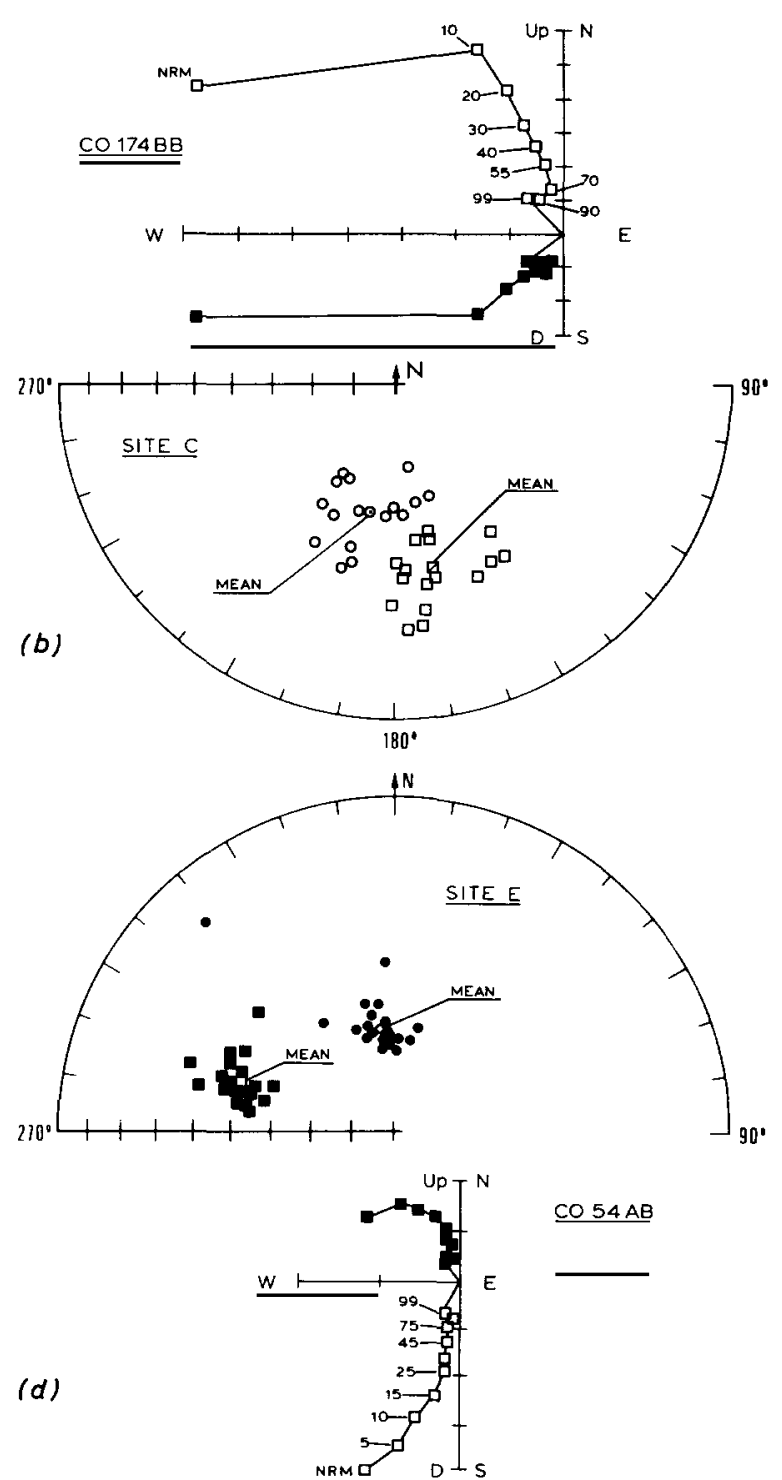

(d)

Fig. 3. Stereographic projection of paleomagnetic mean directions before (circle) and after (square) tilt correction for sites of Miocene age. Open symbols for negative inclinations. Orthogonal demagnetization plot in geographic co-ordinates. Solid squares, projection on the horizontal axes; open circles, projection on vertical plane. Thermal steps are marked in degrees Celsius $\left({ }^{\circ} \mathrm{C}\right)$. 


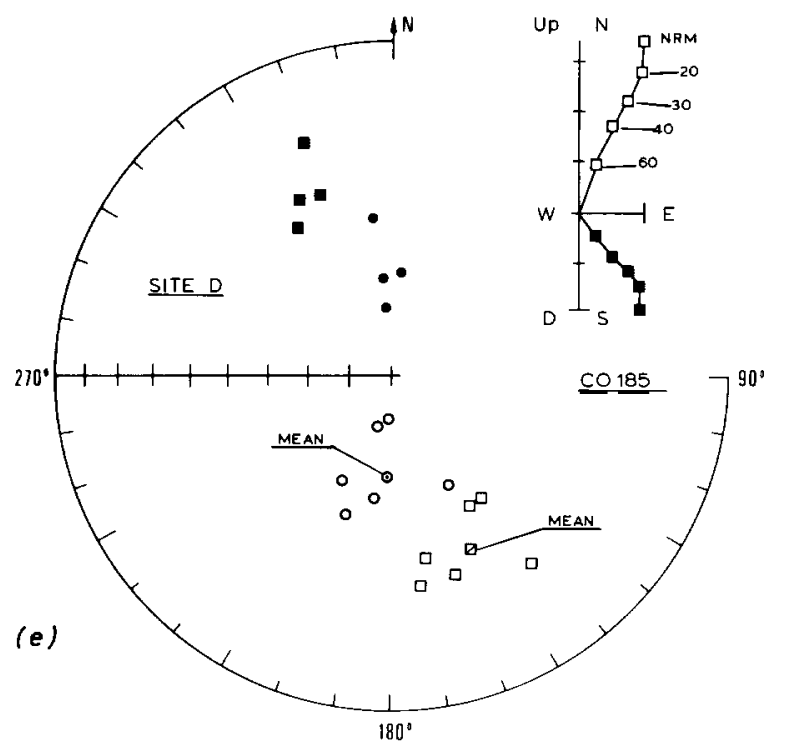

Fig. 3 (continued).

Miocene pole at $80^{\circ} \mathrm{N}, 156^{\circ} \mathrm{E}\left(\alpha_{95}=7^{\circ}\right)$. These pole positions predict paleomagnetic directions for the location of Corsica $\left(42.6^{\circ} \mathrm{N}, 9.0^{\circ} \mathrm{E}\right)$ with declinations and inclinations of $7.5^{\circ} / 49^{\circ}$ $\left(187.5^{\circ} /-49^{\circ}\right.$ for reversed polarity) for the Eocene, and $6.6^{\circ} / 53.5^{\circ}\left(186.6^{\circ} /-53.5^{\circ}\right.$ for reversed polarity) for the Miocene; the present-day geomagnetic and dipole fields give directions of $359^{\circ} / 58.7^{\circ}$ and $0^{\circ} / 61.5^{\circ}$, respectively (Fig. 4. These predicted directions can be compared with the paleomagnetic directions observed in the

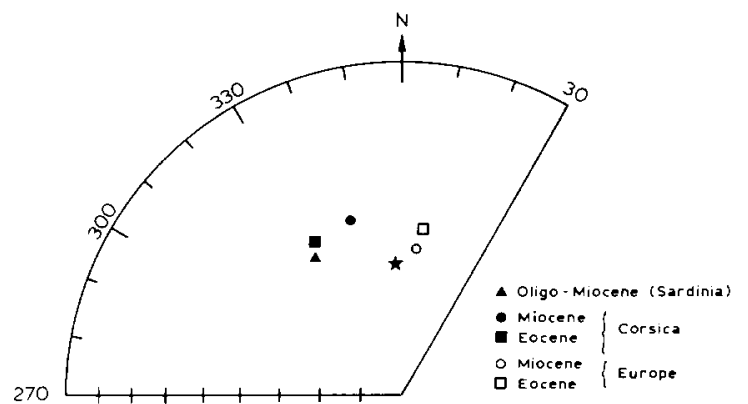

Fig. 4. Comparison of the mean paleomagnetic directions from Corsica (Miocene mean from sites B, C and D; Eocene mean from site F) with data from Sardinia (Montigny et al., 1981) and Europe (computed from the poles of Westphal et al., 1986). Star marks the present-day local field direction. All data downward pointing in lower hemisphere projection.
Eocene and Miocene rocks studied from Corsica, to assess the tectonic significance of the results.

Site $F\left(151^{\circ} /-47.1^{\circ}, \alpha_{95}=4.1^{\circ}\right.$ after tectonic tilt correction) provides perhaps the best estimate in our data for the Eocene of Corsica, on the basis that the direction in either geographic or tilt-corrected coordinates does not correspond to any younger predicted Eurasian field direction, and that the site is clearly autochthonous with a simple structural attitude not affected by local rotations. Comparison of the data from site $\mathrm{F}$ with Eocene predicted direction indicates $36.5^{\circ} \pm 7^{\circ}$ of counter-clockwise rotation, with negligible latitudinal change, of Corsica with respect to stable Eurasia in post-Lutetian times.

The other Eocene sites are more problematical to interpret. Site I suffered penetrative Alpine deformation, which may have affected an original magnetization; alternatively, the reversed polarity magnetization may represent a complex ancient remagnetization. This latter possibility may also account for the two magnetization populations that could be interpreted from the data from site $\mathrm{L}$, neither of which is aligned along the present-day field. However, if the limited palaeomagnetic data from site $L$ are treated as a single group and averaged with the means from sites $G$ and $H$, we find a significant increase in dispersion after tilt correction (Table 1). This is strong evidence that these sites ( $\mathrm{G}, \mathrm{H}$ and $\mathrm{L}$ ) have been remagnetized but it is interesting that the mean direction $\left(153.0^{\circ} /-52.5^{\circ}, \alpha_{95}=13.5^{\circ}\right.$ for $N=3$ sites in geographic co-ordinates) is very similar to the tilt-corrected mean direction of site $\mathrm{F}$, which we regard as a good estimate of the Eocene (Lutetian) paleomagnetic field for Corsica. Remagnetization may therefore have been taken place early in the history of these sediments, after Alpine deformation in the late Eocene, but before the completion of the rotation of Corsica, presumably in the Miocene.

For the Miocene of Corsica, the five accepted sites (A-E) give an overall mean of $6.6^{\circ} / 63.3^{\circ}$, $\alpha_{95}=5.8^{\circ}$, with an eightfold decrease in the precision parameter after tectonic tilt corrections (Table 2). The magnetizations can therefore be regarded as largely secondary. However, although the overall mean direction in geographic co- 
ordinates is not significantly different from the present-day field, remagnetization of at least the Miocene sites which have reversed magnetizations (B, C and D) could not have occurred as recently as the present (Brunhes) interval of normal geomagnetic polarity. It is also noted that the fold test is not as convincingly negative for these reversed polarity sites, with a reduction in the precision parameter by only a factor of 2.3 with tilt correction (Table 2). Although this lack of significant change in dispersion can be attributed to the generally small bedding dips at the Miocene sites (except at site $\mathrm{E}$, which effectively controls the overall fold test), it is interesting to speculate that the magnetizations may perhaps be original. As such, the mean of these three sites B, C and D $\left(164.3^{\circ} /-45.9^{\circ}, \alpha_{95}=9.1^{\circ}\right.$ after tilt correction) would imply $22.3^{\circ} \pm 16^{\circ}$ of counter-clockwise rotation with respect to the Miocene reference pole for stable Eurasia.

\section{Discussion}

Although the generally poor magnetic stabilities, weak magnetizations, and evidence of remagnetizations limit tectonic interpretations of our paleomagnetic results from Tertiary sediments of Corsica, some tentative conclusions can be drawn from the available data. As described above, what is taken to be a representative Eocene magnetization (site F) suggests that Corsica rotated $\sim 37^{\circ}$ counter-clockwise with respect to Eurasia since the Lutetian (Middle Eocene). Palaeomagnetic results from Oligo-Miocene volcanics on Sardinia show a similar amount of rotation. Although the age of the Tertiary rocks studied in Corsica and Sardinia is not precisely the same, the correspondence in the amount of rotation is consistent with Corsica and Sardinia being part of the same tectonic block. Previously, VandenBerg and Zijderveld (1982) considered Sardinia as part of the Adriatic block (Adria), but excluded Corsica from this block because its Paleozoic paleomagnetic directions are very different with respect to those of Adria; our data would suggest a common tectonic history for Sardinia and Corsica since at least the early to middle Tertiary.
The radiometric age estimate of 19 Ma proposed by Montigny et al. (1981) for the completion of rotation of (Corso-)Sardinia was related to the upper Aquitanian stage of the Early Miocene; according to the revised time-scale of Berggren et al. (1985), this would correspond to the middle part of the Burdigalian of the Early Miocene. If the subset of our paleomagnetic results with reversed polarity represent original magnetizations, as speculated above, then a rotation of $-22^{\circ}$ with respect to Eurasia was still to be completed in post-Burdigalian-Langhian time; this would be in better agreement with the interpretation of Bellon et al. (1977), who proposed that the rotation of (Corso-)Sardinia ended not until $15 \mathrm{Ma}$, or Langhian-Serravallian according to the time-scale of Berggren et al. (1985). Additional stratigraphically controlled paleomagnetic data for the Miocene are clearly needed for Corsica and Sardinia to resolve the problem of the timing of the rotation of the Corso-Sardinian block.

\section{Acknowledgements}

The authors thank Professors R. Nardi and A. Puccinelli (University of Pisa, Italy) for useful discussion on geologic and tectonic problems of the sampled areas.

\section{References}

Bellon, H., Coulon, C. and Edel, J.B., 1977. Le déplacement de la Sardaigne. Synthèse des données géochronologiques, magnatiques et paléomagnetiques. Bull. Soc. Géol. Fr., 7(4): 825-831.

Berggren, W.A., Kent, D.V., Flynn, J.J. and Van Couvering, J.A., 1985. Cenozoic geochronology. Geol. Soc. Am. Bull., 96: $1407-1418$.

Bobier, C., 1974. La signification de l'aimantation rémanente des lavas de la série "des ignimbrites inférieures". Conséquence pour l'étude de la rotation du bloc Corso-Sarde durant le Tertiaire. In: Paleogeografia del Terziario sardo nell'ambito del Mediterraneo occidentale. Rend. Sem. Fac. Sci. Univ. Cagliari, 43: 35-56.

Dallan, L. and Puccinelli, A., 1986. Geologia della regione del Nebbio (Corsica Settentrionale). Boll. Soc. Geol. It., 105: $405-414$.

De Jong, K.A., Manzoni, M. and Zijderveld, J.D.A., 1969. Paleomagnetism of the Alghero trachyandesites. Nature, 224: 67. 
De Jong, K.A., Manzoni, M., Stavenga, T., Van Dijk, F., Van der Voo, R. and Zijderveld, J.D.A., 1973. Paleomagnetic evidence for rotation of Sardinia during Early Miocene. Nature, 243: 281-282.

Delcey, R., Limasset, J.C. and Routhier, P., 1964. Les bassins sédimentaires du nord de la Corse: essai de synthèse stratigraphique et aperçu tectonique. Bull. Soc. Géol. Fr., 7(7): 324-333.

Denizot, G., 1952. La structure géologique de la Corse. Rev. sci., 90(3316): 104-119.

Edel, J.B., 1979. Paleomagnetic study of the Tertiary volcanics of Sardinia. J. Geophys., 45: 259-280.

Edel, J.B. and Lortscher, A., 1977. Paléomagnetisme du volcanisme tertiaire de Sardaigne. Nouveaux résultats et synthèse. Bull. Soc. Géol. Fr., 7(19): 815-824.

Edel, J.B., Montigny, R. and Thuizat, R., 1981. Late Paleozoic rotations of Corsica and Sardinia: new evidence from paleomagnetic and K/Ar studies. Tectonophysics, 79: 201223.

Horner, H. and Lowrie, W., 1981. Paleomagnetic evidence from Mesozoic carbonate rocks for the rotation of Sardinia. J. Geophys., 49: 11-19.

Kirschvink, J., 1980. The least-squares line and plane and the analysis of paleomagnetic data. Geophys. J.R. Astron. Soc., 62: 699-718.

Manzoni, M., 1974. Un'interpretazione dei dati paleomagnetici del Terziario della Sardegna ed alcuni nuovi risultati. In: Paleogeografia del Terziario sardo nell'ambito del Mediterraneo occidentale. Rend. Sem. Fac. Sci. Univ. Cagliari, 43: 283-295.

Montigny, R., Edel, J.B. and Thuizat, R., 1981. Oligo-Miocene rotation of Sardinia: $\mathrm{K}-\mathrm{Ar}$ ages and paleomagnetic data of Tertiary volcanics. Earth Planet. Sci. Lett., 54: 261-271.
Nairn, A.E.M. and Westphal, M., 1968. Possible implications of the paleomagnetic study of Late Paleozoic igneous rocks of Northwestern Corsica. Palaeogeogr., Paleoclimatol., Palaeoecol., 5: 179-204.

Nardi, R., Puccinelli, A. and Verani, M., 1971. Sezioni geologiche interpretative nella Balagne sedimentaria (Corsica nord-occidentale). Mem. Soc. Geol. It., 10: 191-202.

Nardi, R., Puccinelli, A. and Verani, M., 1978. Carta geologica della Balagne "sedimentaria" (Corsica) alla scala 1:25000 e note illustrative. Mem. Soc. Geol. It., 97: 3-22.

Storetvedt, K.M. and Markhus, L.A., 1978. Multivectorial magnetization in Late Paleozoic volcanics from North Sardinia; partial remagnetization and rotation. Geophys. J.R. Astron. Soc., 1953: 245-257.

VandenBerg, J. and Zijderveld, J.D.A., 1982. Paleomagnetism in the Mediterranean area. Alpine Mediterranean Geodynamics. Am. Geophys. Union, Geodyn. Ser., 7: 83-112.

Westphal, M., 1976. Contribution du paléomagnetisme à l'étude des déplacements continentaux autour de la Méditerranée occidentale. VPh. D. Thesis, Strasbourg, 304 pp.

Westphal, M., Orsini, J. and Vellutini, P., 1976. Le microcontinent Corso-Sarde, sa position initiale: données paléomagnétiques et raccords géologiques. Tectonophysics, 30: $141-157$

Westphal, M., Bazhenov, M.L., Lauer, J.P., Pechersky, D.M and Sibuet, J.C., 1986. Paleomagnetic implications on the evolutions of the Tethys belt from the Atlantic Ocean to the Pamirs since the Triassic. Tectonophysics, 123: 37-82.

Zijderveld, J.D.A., De Jong, K.A. and Van der Voo, R., 1970 Rotation of Sardinia: paleomagnetic evidence from Permian rocks. Nature, 226: 933-934. 